\title{
Evaluasi Kebijakan Pengendalian Dan Pemberantasan Penyakit Hewan Menular Rabies Di Kabupaten Kapuas Hulu
}

\author{
Maryatiningsih ${ }^{1}$, Sugito ${ }^{2}$, Ahmad Tohardi ${ }^{3}$ \\ 1. Dinas Pertanian dan Pangan Kabupaten Kapuas Hulu \\ 2. Fisip Universitas Tanjungpura \\ 3. Fakultas Pertanian Universitas Tanjungpura
}

Korespondesi Penulis Utama: maryatiningsih1010@gmail.com

\begin{abstract}
The research problem lies in the low success rate of the policy for the control and eradication of rabies infectious animal disease. The research objectives are to evaluate and analyze the policy for the control and eradication of rabies infectious animal disease. The research method was conducted qualitatively through interviews, observation and documentation. The results indicate that the policy for the control and eradication of rabies infectious animal disease observed from the effectiveness, efficiency, responsiveness, equity and accuracy is considered to have quite good results in the context of rabies prevention. Implementation of socialization and vaccination is considered quite effective and efficient even though it has not clearly shown maximum results. However, there has been an increase in preventing rabies; this can be done according to established guidelines and the support of relevant stakeholders. The community basically has a good response to rabies control and eradication policy, especially that related to health. In the aspects of effectiveness, efficiency, responsiveness, equity and accuracy are considered quite optimal due to adequate support and availability of facilities and human resources. However, in terms of adequacy, it has not been fulfilled due to wide reach of the region and the large number of cases that occur as well as the limited budget. Socialization has been implemented in almost all sub-districts in Kapuas Hulu Regency, while vaccination in one sub-district is implemented in all villages up to the hamlet; this proves that the benefits of socialization and vaccination are sufficiently felt by the community. The community has been able to anticipate and take action/first aid if bitten by rabies-transmitting animals and immediately go to the nearest community health center to get an Anti-Rabies Vaccine. Overall, the policy for the control and eradication of rabies infectious animal disease is quite good although there are still areas that have not been reached. Therefore, there are areas that are still at risk of rabies because the mobile nature of rabies-transmitting animals, especially dogs. According to the evaluation theory of William M. Dunn, policy evaluation on for the control and eradiation of rabies infectious animal disease is considered effective in the aspect of Effectiveness, Efficiency, Equity, Responsiveness and Accuracy but it has not been considered effective in the aspect of Adequacy.
\end{abstract}

Key words : Policy evaluation, Control and eradication, Rabies 


\section{PENDAHULUAN}

Rabies atau penyakit anjing gila adalah penyakit hewan menular yang disebabkan oleh virus dari genus Lyssavirus (dari bahasa Yunani Lyssa yang berarti mengamuk atau kemarahan), bersifat akut serta menyerang susunan syaraf pusat, hewan berdarah panas dan manusia. Rabies berasal dari bahasa Latin "robere" yang artinya marah, menurut bahasa Sansekerta "rabhas" yang berarti kekerasan (Pusat Data dan Informasi Kementerian Kesehatan RI, 2016).

Untuk wilayah Indonesia hingga saat ini sudah 25 (dua puluh lima) provinsi tertular rabies dan hanya 9 (sembilan) provinsi di Indonesia yang masih tetap bebas rabies, yaitu Nusa Tenggara Barat, Papua, Papua Barat, Bangka Belitung, Kepulauan Riau, DKI Jakarta, Daerah Istimewa Yogyakarta, Jawa Tengah dan Jawa Timur.

Pengendalian

penanggulangan penyakit hewan merupakan penyelenggaraan kesehatan hewan dan kesehatan lingkungan dalam bentuk pengamatan

dan pengidentifikasian, pencegahan, pengamanan, pemberantasan dan/atau pengobatan; di mana urusan kesehatan hewan dilakukan dengan pendekatan pemeliharaan, peningkatan kesehatan (promotif), pencegahan penyakit (preventif), penyembuhan penyakit (kuratif) dan pemulihan kesehatan (rehabilitasi) yang dilaksanakan secara menyeluruh, terpadu dan berkesinambungan, seperti yang diamanatkan dalam Undang-Undang Nomor 18 Tahun 2009 tentang
Peternakan dan Kesehatan Hewan sebagaimana telah diubah dengan Undang-Undang Nomor 41 Tahun 2014.

Dalam rangka melindungi dan meningkatkan kualitas sumber daya hewan, meningkatkan derajat kesehatan masyarakat, hewan dan lingkungan, meningkatkan usaha peternakan dan kesehatan hewan sebagaimana diamanatkan dalam Undang-Undang dimaksud, maka Pemerintah Provinsi Kalimantan Barat mengatur Penyelenggaraan Peternakan dan Kesehatan Hewan dalam suatu Peraturan Daerah Provinsi Kalimantan Barat Nomor 2 Tahun 2016 tentang Penyelenggaraan Peternakan dan Kesehatan Hewan yang merupakan upaya untuk menciptakan suasana yang kondusif dalam penyelenggaraan peternakan dan kesehatan hewan serta penegakan dan pemberian kepastian hukum, yaitu dengan pemberian sanksi terhadap perbuatan yang dapat menimbulkan kerugian baik kepada daerah maupun kepentingan orang banyak.

Kabupaten Kapuas Hulu sendiri sampai saat ini belum menetapkan Peraturan Daerah yang mengatur tentang penyelenggaraan peternakan dan kesehatan hewan, namun untuk mengendalikan dan memberantas penyakit rabies yang sudah menyebar hampir di seluruh kabupaten/kota di wilayah Kalimantan Barat, maka Pemerintah Kabupaten Kapuas Hulu pada tanggal 19 Agustus 2015 telah mengeluarkan Keputusan Bupati Kapuas Hulu Nomor 340 tahun 2015 tentang 
Penetapan Kejadian Luar Biasa (KLB) Penyakit Rabies di Kabupaten Kapuas Hulu. Hal ini sebagai tindak lanjut terjadinya kasus gigitan di Desa Selaup Kecamatan Bunut Hulu pada akhir bulan April 2015 yang menyebabkan 1 (satu) orang meninggal dunia yang didukung hasil uji sampel kepala anjing dari Desa Segitak Kecamatan Bunut Hulu yang positif rabies pada bulan Juli 2015.

Sebelum Status Kejadian Luar Biasa (KLB) Penyakit Rabies di Kabupaten Kapuas Hulu ditetapkan, maka untuk mengantisipasi masuknya penyakit rabies di Kabupaten Kapuas Hulu dan menindaklanjuti Surat Dinas Peternakan dan Kesehatan Hewan Provinsi Kalimantan Barat Nomor 524/197/VII-b/02.15 tanggal 2 Februari 2015 tentang kewaspadaan terhadap rabies serta mengingat Kabupaten Kapuas Hulu merupakan daerah terancam, Pemerintah Kabupaten Kapuas Hulu telah mengeluarkan Instruksi Bupati Nomor 1 Tahun 2015 tanggal 2 Maret 2015 tentang Pencegahan Penyakit Rabies.

Instruksi ini ditujukan kepada seluruh Kepala Desa dan Lurah se Kabupaten Kapuas Hulu, yang isinya agar Kepala Desa dan Lurah se Kabupaten Kapuas Hulu membuat Keputusan Desa/Keputusan Lurah sebagai langkah pencegahan penyakit rabies. Keputusan Kepala Desa/Lurah bertujuan agar penyakit rabies tidak menyebar di desa / kelurahan mereka khususnya dan Kabupaten Kapuas Hulu umumnya. Selain Instruksi Bupati Kapuas Hulu Nomor 1 Tahun 2015, pada tanggal yang sama juga telah dikeluarkan Instruksi Bupati Kapuas Hulu Nomor 2 Tahun 2015 tentang Kewaspadaan Terhadap Rabies.

Instruksi ini ditujukan kepada Anggota Komisi Kabupaten Pengendalian Zoonosis Kapuas Hulu, yang merupakan tindak lanjut dari Peraturan Presiden Nomor 30 tahun 2011 tentang Pengendalian Zoonosis dan Surat Dinas Peternakan dan Kesehatan Hewan Provinsi Kalimantan Barat Nomor 524/1486/VII-b tanggal 3 Oktober 2015 tentang Tindak Lanjut Pernyataan Provinsi Kalimantan Barat Bebas Penyakit Rabies (Anjing Gila) serta Surat Nomor 524/197/VII-b/02.15 tanggal 2 Fabruari 2015 tentang Kewaspadaan terhadap Rabies. dengan Kalimantan Tengah dan daerah yang tertular Rabies serta mencegah masuknya HPR dari daerah tertular ke wilayah Kabupaten Kapuas Hulu.

Kalimantan Barat selama 3 (tiga) tahun merupakan provinsi ke 2 (dua) setelah Sulawesi Utara yang mempunyai kasus kematian tertinggi akibat rabies (Lyssa) dengan jumlah kematian sebanyak 14 kasus pada tahun 2014. Pada tahun 2015 menduduki posisi ke 7 (tujuh) setelah Sulawesi Utara (28 kasus), Bali (15 kasus), Sumatera Utara (14 kasus), Kalimantan Tengah (8 kasus), Sumatera Barat (7 kasus) dan Bengkulu (6 kasus); sedangkan pada tahun 2016 kembali menduduki posisi ke 2 (dua) dengan 12 kasus setelah Sulawesi Utara dengan 21 kasus. Hal ini menunjukan bahwa Kalimantan Barat sangat rawan terhadap penyakit rabies. 
Mengingat kasus gigitan HPR semakin meluas dengan beberapa korban meninggal dunia baik di Provinsi Kalimantan Barat maupun di Indonesia, maka pemerintah baik pusat maupun daerah berupaya melaksanakan kebijakan pengendalian dan pemberantasan penyakit hewan menular rabies terutama daerah-daerah yang tertular atau terancam penyakit rabies termasuk Kabupaten Kapuas Hulu, antara lain dengan melaksanakan sosialisasi, vaksinasi dan eliminasi terhadap HPR liar atau tidak berpemilik dan HPR yang diliarkan serta menunjukan gejala.

Kebijakan pengendalian dan pemberantasan penyakit hewan menular rabies merupakan salah satu kebijakan pemerintah yang bertujuan untuk menurunkan kematian akibat rabies melalui penanganan kasus Gigitan Hewan Penular Rabies (GHPR) untuk selanjutnya membebaskan Indonesia dari rabies di tahun 2030.

Penyakit rabies di Kalimantan Barat umumnya dan Kabupaten Kapuas Hulu khususnya sampai saat ini masih belum dapat dikendalikan, di mana masih terdapat laporan kasus GHPR dan sulit dilakukan diagnosa klinis di lapangan, mengingat HPR (Hewan Penular Rabies) yang telah menggigit umumnya langsung dibunuh oleh pemiliknya atau dibuang ke hutan atau perkebunan sawit. Seyogyanya untuk mengetahui HPR terinfeksi virus atau tidak harus dilakukan observasi selama 14 (empat belas) hari, jika sebelum 14 hari HPR mati maka diindikasi HPR tersebut terinveksi virus rabies, tetapi sebaliknya jika dalam waktu 14 hari HPR masih tetap hidup dan sehat maka bisa dipastikan HPR tidak terinfeksi virus rabies; hal ini diperkuat lagi dengan hasil uji sampel otak kepala HPR di laboratorium.

Pada tahun 2015 saat Kabupaten Kapuas Hulu ditetapkan sebagai Kejadian Luar Biasa Penyakit Rabies, Pemerintah Daerah menganggarkan dana yang cukup besar melalui dana APBD-Perubahan untuk kebijakan pengendalian dan pemberantasan rabies dengan beberapa kegiatan yang melibatkan instansi lainnya sampai ke tingkat desa. Untuk tahun berikutnya terjadi penurunan anggaran yang signifikan, yang disebabkan karena terjadinya pemangkasan anggaran pada semua Organisasi Perangkat Daerah (OPD) Kabupaten Kapuas Hulu, hal ini tentu saja berpengaruh terhadap pelaksanaan kebijakan pengendalian dan pemberantasan rabies di Kabupaten Kapuas Hulu.

\section{METODE PENELITIAN}

Jenis Penelitian yang digunakan dalam penelelitian ini adalah jenis penelitian evaluasi. Menurut Sugiyono $(2018,3)$, penelitian evaluasi (evaluation research) merupakan evalusi program, sebagai metode ilmiah yang digunakan untuk mengetahui efektifitas dan efisiensi sebuah program, kebijakan, proyek dan aktivitas tertentu baik yang telah lalu, yang sedang terjadi, dan usulan program yang akan datang. Penelitian evaluasi dilakukan berdasarkan standar rencana dan tujuan dari program yang hasilnya dapat digunakan sebagai bahan 
pertimbangan untuk meningkatkan kualitas perumusan, implementasi dan hasil dari suatu proyek, kebijakan dan program.

Pendekatan atau paradigma yang digunakan dalam penelitian ini adalah pendekatan kualitatif yang merupakan suatu model penelitian yang bersifat humanistik, dimana manusia dalam penelitian ini ditempatkan sebagai subyek utama dalam suatu peristiwa sosial.

Penelitian ini dilaksanakan di Kabupaten Kapuas Hulu dengan pelaksana kebijakan pengendalian dan pemberantasan penyakit hewan menular rabies adalah Seksi Kesehatan Hewan dan Kesehatan Masyarakat Veteriner (Kesmavet) dan Dinas Pertanian dan Pangan Kabupaten Kapuas Hulu. Adapun yang menjadi pertimbangan Penulis memilih lokasi penelitian tersebut adalah :

a. Dinas Pertanian dan Pangan Kabupaten Kapuas Hulu merupakan institusi yang memiliki tugas dan fungsi serta wewenang mengeluarkan kebijakan dan mengawasi kebijakan dalam bidang peternakan, termasuk dalam kebijakan pengendalian dan pemberantasan penyakit hewan menular rabies di Kabupaten Kapuas Hulu; sementara Bidang Peternakan khususnya Seksi Kesehatan Hewan dan Masyarakat Veteriner merupakan pelaksana kegiatan pengendalian dan pemberantasan penyakit hewan menular rabies.

b. Kabupaten Kapuas Hulu terdapat masalah dengan kasus gigitan hewan penular rabies yang cukup tinggi selama 3 (tiga) tahun berturut-turut.

Menurut Arikunto

(2003:122)

subjek penelitian adalah subjek yang dituju untuk diteliti oleh peneliti. Dalam penelitian ini, untuk menentukan subjek penelitian dengan menggunakan purposive, yaitu suatu teknik untuk menentukan informan berdasarkan tujuan atau keperluan yang ditetapkan peneliti sendiri. Menurut Kriyantono dalam buku "Teknik Praktis Komunikasi" (2007:154), teknik purposive mencakup orang-orang yang diseleksi berdasarkan kriteria-kriteria tertentu yang dibuat berdasarkan tujuan penelitian. Penelitian ini menggunakan purposive karena informan menjadi sumber informasi yang mengetahui tentang penelitian yang sedang diteliti.

Sesuai dengan pendekatan kualitatif yang digunakan dalam penelitian ini, maka instrumen utama (key instrumen) dalam penelitian ini adalah penulis sendiri selaku peneliti, dibantu dengan pedoman wawancara, pedoman observasi dan alat dokumenter.

Teknis analisis data yang digunakan dalam penelitian ini adalah dengan menggunakan 3 komponen analisis, yaitu :

a. Meringkas (reduksi), hasil observasi dan wawancara yang dilakukan direduksi dalam bentuk ringkasanringkasan seperti intisari atau kode yang dapat dimengerti untuk selanjutnya dilakukan editing terbatas dan pemberian nomor informan, 
tujuannya agar data yang dianalisis merupakan data-data yang benar-benar berkaitan dengan masalah penelitian.

b. Memaparkan (display), hasil-hasil observasi dan wawancara yang dilakukan dugaan dalam lembaranlembaran kutipan, catatan atau gambar yang mudah dibaca sehingga memudahkan dalam melakukan analisa data.

c. Menyimpulkan (verifikasi), dari hasil obserbasi dan wawancara yang telah diringkas dan diprsentasikan kemudian diambil beberapa kesimpulan yang paling relevan dengan masalah yang diteliti.

\section{HASIL DAN PEMBAHASAN}

Kabupaten Kapuas Hulu merupakan salah satu dari 14 (empat belas) kabupaten/kota di Provinsi Kalimantan Barat, memiliki luas wilayah sekitar $31.162,87 \mathrm{~km}^{2}$ terbagi menjadi 23 wilayah kecamatan dengan 278 desa dan 4 kelurahan, ini berarti bahwa Kabupaten Kapuas Hulu mencakup 21,23\% luas wilayah Provinsi Kalimantan Barat dan sekaligus merupakan Kabupaten terluas kedua setelah Kabupaten Ketapang yang luasnya sekitar 31.240,74 km².

Kabupaten Kapuas Hulu merupakan Kabupaten otonom di Wilayah Propinsi Kalimantan Barat yang dibentuk berdasarkan UU Darurat No. 3 tahun 1953 tanggal 13 Januari 1953 tentang Pembentukan Daerah Tingkat II di Kalimantan Barat.

Keadaan penduduk Kabupaten Kapuas Hulu, diperkirakan sebanyak 245.998 orang, yang terdiri dari 125.192 jiwa penduduk laki-laki $(50,89 \%)$ dan 120.806 jiwa penduduk perempuan $(49,11 \%)$ serta dengan ratio jenis kelamin sebesar $103,63 \%$.

Adapun hasil penelitian ini didasarkan pada Model Willniam N Dunn yang membahas evaluasi meliputi 6 ( enam ) aspek yaitu efektivitas, efisisensi, kecukupan, perataan, responsibilitas dan ketepatan.

\section{Tingkat Efektivitas Kebijakan Pengendalian dan Pemberantasan Penyakit Hewan Menular Rabies.}

Dengan adanya Keputusan Bupati Kapuas Hulu tersebut membuat Dinas Pertanian dan Pangan Kabupaten Kapuas Hulu (sebelumnya bernama Dinas Pertanian Tanaman Pangan dan Peternakan Kabupaten Kapuas Hulu) harus bekerja ekstra, di antaranya dengan membentuk tim yang bertugas untuk mengendalikan dan menanggulangi penyakit rabies melalui Surat Keputusan Bupati Kapuas Hulu Nomor 347 tahun 2015 tanggal 24 Agustus 2015 tentang Pembentukan Satuan Tugas Komando Tanggap Darurat Pengendalian dan Penanggulangan Kejadian Luar Biasa Rabies di Kabupaten Kapuas Hulu guna mengantisipasi semakin meluasnya kasus gigitan hewan penular rabies (HPR).

Berdasarkan hasil wawancara Penulis dengan Bapak Kepala Dinas Pertanian dan Pangan Kabupaten Kapuas Hulu diperoleh informasi sebagai berikut :

" Upaya awal yang dilakukan Dinas Pertanian dan Pangan dalam menanggulangi penyakit rabies adalah 
dengan mengeluarkan Keputusan Kepala Daerah yang bertujuan sebagai dasar/pedoman dalam melakukan sebuah kegiatan serta menunjuk beberapa instansi terkait sehingga dalam bekerjasama melalui pembentukan sebuah Surat Keputusan, penanggulangan rabies di Kabupaten Kapuas Hulu dapat ditangani dengan cepat. Beliau juga menekankan bahwa dengan berjangkitnya wabah penyakit rabies di Kabupaten Kapuas Hulu perlu dilakukan tindakan pengamatan, pencegahan, pengendalian dan pemberantasan penyakit anjing gila (rabies) secara terkoordinasi dengan instansi terkait"

Dari data pelaksanaan sosialisasi menunjukkan bahwa masing-masing satuan sesuai Keputusan Bupati Kapuas Hulu telah melaksanakan tugasnya dengan maksimal, di mana terlihat dari jumlah kasus gigitan di tahun 2015 sebanyak 196 kasus gigitan turun menjadi 131 kasus gigitan di tahun 2016 walaupun kemudian di tahun 2017 jumlah kasus gigitan meningkat kembali menjadi 185 kasus gigitan dengan masing-masing satu orang meninggal dunia, namun pada tahun berikutnya 2018 dan 2019 untuk perbandingan, terjadi penurunan kasus gigitan.

Berdasarkan uraian hasil wawancara dengan beberapa informan, maka penulis berpendapat bahwa pelaksanaan kebijakan pengendalian dan pemberantasan penyakit hewan menular rabies di Kabupaten Kapuas Hulu sudah cukup efektif. Hal ini dikarenakan pihak Dinas Pertanian dan Pangan Kabupaten Kapuas Hulu dalam pengendalian dan pemberantasan penyakit hewan menular rabies sudah berpedoman pada aturan yang telah ditetapkan yaitu Keputusan Bupati Kapuas Hulu Nomor 340 tahun 2015 tentang Penetapan Kejadian Luar Biasa Penyakit Rabies, sehingga secara khusus tujuan dari kebijakan pengendalian dan pemberantasan penyakit hewan menular rabies itu sendiri dapat dirasakan manfaatnya oleh masyarakat khususnya wilayah yang terdampak rabies; yang mana pelaksanaan kebijakan pengendalian dan pemberantasan penyakit hewan menular rabies adalah untuk mengantisipasi menyebarnya penyakit rabies sehingga kasus gigitan hewan penular rabies dapat diminimalisir dan dikendalikan serta kematian pada manusia dapat dihindari.

Kegiatan pengendalian dan pemberantasan penyakit hewan menular rabies yang dilakukan Dinas Pertanian dan Pangan juga dirasakan cukup baik. Walaupun pengendalian dan pemberantasan penyakit hewan menular rabies ini belum secara jelas memperlihatkan hasil yang maksimal namun sudah ada peningkatan dalam mencegah penyakit rabies. Namun apabila dilihat dari rendahnya respon masyarakat terhadap laporan kasus GHPR dan sulitnya melakukan diagnosis klinis dilapangan merupakan salah satu indikator dalam menilai kriteria belum efektifnya kebijakan pengendalian dan pemberantasan penyakit rabies yang dilakukan oleh Pemerintah Kabupaten Kapuas Hulu.

Adanya konsep one health dapat dilakukan secara intensif dan sedini 
mungkin dalam mencegah meluasnya penyakit rabies serta adanya sinergitas antara pelaku kepentingan baik tingkat kabupaten, kecamatan maupun aparat desa sampai ke dusun dalam pelaksanaan kebijakan tersebut menurut penulis akan dapat mendukung efektifnya pelaksanaan pengendalian dan pemberantasan penyakit menular rabies di Kabupaten Kapuas Hulu.

Selain itu, walaupun dukungan pembuat kebijakan yang dibutuhkan sudah sangat maksimal namun peran masyarakat dalam meningkatkan kesadaran akan pentingnya pengendalian dan pemberantasan penyakit hewan menular rabies juga perlu ditingkatkan, dimana peran Pemerintah dalam mendukung pelaksanaan kegiatan pengendalian dan pemberantasan penyakit rabies sangat penting dalam mewujudkan efektivitas kebijakan. Sinergi sektor hewan, manusia dan lingkungan perlu dilakukan melalui pendekatan lima pilar yang meliputi sosiokultural, teknis, organisasi, politik, dan sumber daya. Tanpa dukungan dari pembuat kebijakan misalnya, sulit mewujudkan penanggulangan zoonosis terintegrasi. Pemerintah diharapkan mampu secara efektif untuk melaksanakan kebijakan pengendalian dan pemberantasan penyakit Rabies sehingga Program Pemerintah untuk mencegah menularnya penyakit rabies dapat tercapai dengan efektif.

\section{Tingkat Efisiensi Kebijakan Pengendalian dan Pemberantasan Penyakit Hewan Menular Rabies}

Dunn (2003:430) berpendapat bahwa "Efesiensi (effeciency) berkenaan dengan jumlah usaha yang diperlukan untuk mencapai tingkat efektivitas tertentu. Efesiensi yang merupakan sinonim dari rasionalitas ekonomi, adalah merupakan hubungan antara efektiivitas dan usaha, yang terakhir umumnya diukur dari ongkos moneter. Terkait dengan program atau kebijakan pengendalian dan pemberantasan penyakit rabies yang dilakukan di Kabupaten Kapuas Hulu dapat dikatakan sudah efesien, dikarenakan adanya dukungan dan ketersediaan sarana dan SDM secara operasional yang cukup memadai. Hal ini membuktikan bahwa pengendalian dan pemberantasan penyakit rabies dapat dikatakan sudah efektif karena adanya dukungan instansi terkait dan sudah melaksanakan tugasnya dengan baik.

Adapun dukungan dana dari Pemerintah Kabupaten yang dianggarkan dalam Anggaran Pendapatan dan Belanja Daerah (APBD) dalam mendukung kebijakan pengendalian dan pemberantasan penyakit rabies dari tahun ke tahun (tahun 2015 sampai dengan tahun 2017) mengalami penurunan, penulis berpendapat bahwa kebijakan pengendalian dan pemberantasan penyakit rabies sudah dilakukan secara efisien, hal ini dapat dilihat dari adanya dukungan dana dimana dalam anggaran tersebut telah terbagi dalam rekening seperti honorarium Tim Koordinasi, Alat Tulis Kantor yang diperlukan untuk 
kegiatan, biaya rapat-rapat untuk koordinasi Tim, Biaya Konsumsi untuk mendukung rapat serta biaya perjalanan dinas dan bantuan transportasi dalam rangka sosialisasi, vaksinasi, pengambilan sampel dan observasi, pengiriman sampel ke laboratorium, pembelian vaksin dan peralatan pendukungnya serta pemantauan dan pengawasan program kegiatan tersebut.

Dukungan anggaran merupakan salah satu sumber daya yang harus ada dalam penerapan kebijakan. Tanpa ada dukungan dana maka kebijakan tersebut tidak akan bisa berjalan secara optimal. Dalam hal ini, Pemerintah Daerah Kabupaten Kapuas Hulu telah mengalokasikan anggaran untuk kegiatan kebijakan pengendalian dan pemberantasan penyakit hewan menular rabies sebesar Rp. 266.050.000 di tahun 2017 akan tetapi pada tahun 2018 besaran anggaran hanya Rp. 113.130.000,- dan di tahun 2019 sebesar

145.689.000,-. Walaupun terjadi penurunan dari tahun ke tahun namun dukungan ini dirasakan sudah cukup membuktikan bahwa dukungan Pemerintah sangat serius dalam melaksanakan kegiatan ini.

Adanya keterbatasan anggaran dalam pelaksanaan kegiatan pengendalian dan pemberantasan penyakit hewan menular rabies, jika tidak dikelola dengan baik dapat menjadikan kegiatan tidak berjalan dengan maksimal. Hal ini akan mempengaruhi efisiensi waktu dari pelaksanaan pengendalian dan pemberantasan penyakit hewan menular rabies itu sendiri; sehingga Penulis berpendapat berdasarkan hasil wawancara bahwa efisiensi pelaksanaan kebijakan pengendalian dan pemberantasan penyakit hewan menular rabies di Kabupaten Kapuas Hulu sudah berjalan dengan efisien apabila dinilai dari segi pemanfaatannya bagi masyarakat karena dapat menekan kasus gigitan HPR dan kasus kematian pada manusia serta meningkatkan nilai ekomonis. Selain itu secara opersional kebijakan pengendalian dan pemberantasan penyakit hewan menular rabies telah didukung oleh Sumber Daya Manusia yang memadai.

Jika dilihat dari besaran anggaran dari tahun ke tahun maka pelaksanaan kegiatan pengendalian dan pemberantasan penyakit hewan menular rabies yang dikoordinir oleh Dinas Pertanian dan pangan Kabupaten Kapuas Hulu sudah dapat dikatakan efisien karena di tahun 2017 anggaran sudah jauh berkurang hampir setengah dari anggaran tahun 2016. Pengurangan anggaran terjadi karena honorarium Petugas Rabies Center di 11 kecamatan dihapus dan honor Satuan Tugas Komando Tanggap Darurat dikurangi menyesuaiakan anggaran yang telah dialokasikan pada Dinas Pertanian dan Pangan Kabupaten Kapuas Hulu khususnya Bidang Peternakan.

Pengurangan anggaran tersebut tidak serta merta mengakibatkan bertambahnya kasus kematian pada manusia walaupun kasus gigitan HPR meningkat karena masyarakat sudah mengetahui cara penanggulangan dini jika tergigit HPR. Terjadinya kasus 
kematian pada manusia di tahun 2017 lebih disebabkan karena terlambatnya korban melapor dan berobat ke layanan kesehatan terdekat.

\section{Tingkat Kecukupan Kebijakan Pengendalian Pemberantasan Penyakit Hewan Menular Rabies.}

Salah satu faktor yang sangat penting diketahui dalam menentukan keberhasilan atau kegagalan sebuah program yang dilaksanakan adalah kecukupan. Aspek ini sangat berpengaruh pada pencapaian tujuan dari pada kebijakan, apabila aspek kecukupan terpenuhi dalam suatu program, maka secara otomatis kegiatan yang akan dilaksanakan dapat berjalan dengan baik dan bisa dipastikan program tersebut akan berhasil meskipun terdapat kendala dalam program akan tetapi tetap menemukan solusi dalam penyelesaiannya, apabila sumber daya yang digunakan mendukung dalam operasionalisme program dan kebutuhan bagi penerima manfaat program terpenuhi.

Hasil wawancara Penulis bersama dengan Kepala Seksi Keswan dan Kesmavet diperoleh informasi bahwa :

"bahwa pengendalian dan pemberantasan penyakit hewan menular rabies sangat bermanfaat dalam mengantisipasi penyakit menular namun jumlah anggaran pengendalian dan pemberantasan penyakit hewan menular rabies dirasakan belum mampu memenuhi kegiatan yang dilaksanakan. Hal ini menyebabkan program pengendalian dan pemberantasan dapat dikatakan masih kurang dari segi kecukupan karena kelompok sasaran kurang merasakan adanya manfaat dari kebijakan tersebut sehingga belum memberikan manfaat dan pengaruh yang signifikan terutama dalam menunjang pengendalian dan pemberantasan penyakit rabies di Kabupaten Kapuas Hulu dimasa yang akan datang"

Informasi tersebut senada dengan informasi yang Penulis peroleh dari petugas vaksinasi yang ada di Kecamatan yaitu :

" Luasnya jangkauan wilayah yang harus dipantau dan diawasi serta banyaknya kasus gigitan yang tersebar di beberapa Kecamatan yang jauh dari rumah sakit atau pusat layanan kesehatan masyarakat membuat kerja ekstra bagi petugas di lapangan maupun perangkat desa serta Polsek, sehingga walaupun dengan sarana dan keterbatasan yang ada kami tidak mampu untuk menjangkau semua wilayah karena letak geografis yang sangat sulit untuk dijangkau"

Dari hasil wawancara tersebut di atas, Penulis dapat menyimpulkan bahwa Pengendalian dan pemberantasan penyakit menular apabila dilihat dari faktor kecukupan memang terlihat belum efektif mengingat luasnya jangkauan wilayah yang harus dipantau dan diawasi serta banyaknya kasus gigitan yang tersebar di beberapa Kecamatan yang jauh dari rumah sakit atau pusat layanan kesehatan masyarakat memerlukan perhatian yang lebih dari Pemerintah Daerah khususnya peran anggota Dewan. Agar pengendalian dan pemberantasan penyakit menular dapat berjalan dan dapat memberikan manfaat atau pengaruh bagi masyakat Kabupaten Kapuas Hulu 
hendaknya pihak terkait baik pemerintah daerah (eksekutif), legislatif maupun pihak lain yang terkait perlu melakukan evaluasi terhadap kebijakan tersebut terutama dari segi anggaran. Hasil evaluasi tersebut diharapkan bisa melahirkan kebijakan yang dapat memberikan manfaat bagi masyarakat khususnya dalam meminimalisir penyakit rabies.

\section{Tingkat ResponsiveKebijakan Pengendalian dan Pemberantasan Penyakit Hewan Menular Rabies}

Berdasarkan hasil wawancara Penulis dengan Kepala Seksi Keswan Kesmavet maka diperoleh informasi sebagai berikut : " bahwa sosialisasi dilakukan di daerah yang menjadi tempat Endemis Rabies dan Daerah Tertular (Seberuang, Semitau, Silat Hulu, Silat Hilir, Bunut Hulu dan Putussibau Utara), Daerah Terancam (Badau, Empanang, Puring Kencana, Boyan Tanjung, Mentebah, Kalis, Putussibau Selatan, Bika. Embaloh Hulu, Embaloh Hilir, Pengkadan, Suhaid dan Batang Lupar) serta Daerah Bebas (Hulu Gurung, Jongkong, Bunut Hilir dan Selimbau. Adanya pembagian zona daerah tersebut dimaksudkan agar kebijakan pengendalian dan pemberantasan penyakit hewan menular rabies yang dilaksanakan bisa tepat sasaran, merata, efektif dan efisien.

Dari hasil wawancara tersebut menggambarkan bahwa pemerataan dalam sosialisasi yang hampir dilakukan di seluruh wilayah Kabupaten Kapuas Hulu sudah dapat dirasakan manfaatnya oleh masyarakat terdampak, sehingga Penulis berpendapat bahwa pelaksanaan kebijakan pengendalian dan pemberantasan penyakit hewan menular rabies apabila dilihat dari aspek perataan sudah cukup optimal dilakukan. Hal ini sudah cukup membuktikan bahwa melalui sosialisasi dan pemberian vaksin cukup efektif dalam mengendalikan dan memberantas penyakit hewan menular rabies.

\section{Tingkat Perataan Kebijakan Pengendalian dan Pemberantasan Penyakit Hewan Menular Rabies}

Dalam penelitian ini berbicara mengenai bagaimana respon dari masyarakat terhadap sosialisasi yang dilakukan oleh Dinas Pertanian dan Pangan Kabupaten Kapuas Hulu selaku unsur pelaksana teknis dan begitu pula sebaliknya. Kebijakan ini dapat dikatakan efektif ketika di antara kedua bagian tersebut saling memberikan respon yang baik terhadap kebijakan tersebut. Dinas Pertanian dan Pangan pun diharuskan dapat memberikan respon yang tepat sasaran untuk memenuhi tuntutan dari masyarakat, yang mana masyarakat sebagai unsur penerima vaksin yang seharusnya layak untuk didahulukan karena harus mempertimbangkan ketersediaan vaksin dan anggaran yang terbatas . Dampak dari kebijakan yang efektif dan efisien pastinya akan dirasakan oleh masyarakat sebagai unsur penerima manfaat dari suatu kebijakan.

Dalam rangka meningkatkan rasa antusias serta kepedulian masyarakat terhadap kebijakan pengendalian dan 
pemberantasan penyakit hewan menular rabies sangat diperlukan bimbingan secara khusus serta dilakukan pendekatan secara persuasif dan tetap dilaksanakan sosialisasi. Selain itu diperlukan adanya suatu aturan dari Desa melalui Keputusan Desa atau Peraturan Desa (PERDES) tentang rabies, di mana salah satu pasalnya memuat tentang kewajiban pemilik HPR untuk vaksin HPR nya dan melaporkan ke Kepala Desa atau Penyuluh Pertanian jika ada kasus gigitan HPR sehingga masyarakat benarbenar paham akan bahaya rabies.

Apabila dilihat dari perilaku masyarakat terutama masyarakat terdampak masih terdapat masyarakat yang tidak mau memberikan vaksin kepada anjingnya dengan alasan anjing setelah divaksin tidak mau menggonggong, menjadi malas, tidak mau diajak berburu ataupun anjing akan mati. Selain itu perilaku masyarakat dalam mengkandangkan anjing peliharaanya masih sangat rendah, sehingga hal ini bisa menjadi pemicu cepatnya virus rabies berkembang; namun sikap masyarakat terhadap kebijakan tersebut terutama dalam hal perlunya pembuatan peraturan tentang Rabies sangat responsive. Hal ini menunjukan bahwa masyarakat terutama tokoh masyarakat sangat berharap adanya Peraturan Desa (PERDES) tentang Rabies sehingga dapat meningkatkan kesadaran masyarakat terhadap resiko dan bahaya rabies.

Dari hasil wawancara di beberapa desa dan kecamatan seperti desa Sejiram dan desa Tajau Mada di Kecamatan
Seberuang, desa Nanga Dangkan Kecamatan Silat Hulu, desa Nanga Payang Kecamatan Bunut Hulu, desa Sukamaju Kecamatan Putusibau Selatan, Penulis dapat menyimpulkan bahwa sebagian besar informan telah memiliki sikap dan pengetahuan yang mengarah pada perilaku yang baik karena telah dapat memberikan pertolongan pertama pada saat terjadi gigitan anjing. Para informan rata-rata sudah mengetahui tindakan yang akan dilakukan jika terjadi kasus gigitan HPR. Hal ini dapat penulis simpulkan bahwa perilaku para informan sangat baik terutama dalam melakukan pertolongan pertama terhadap gigitan HPR. Meskipun ada beberapa informan telah memiliki sikap, pengetahuan dan perilaku yang baik akan tetapi masih terdapat beberapa informan yang berperilaku kurang baik. Hal tersebut dapat dilihat dari masih adanya sebagian informan yang belum melaksanakan tindakan-tindakan yang mengarah pada menjaga dan memelihara hewan peliharaan mereka untuk mencegah penyakit rabies ini. Masih ada beberapa informan yang belum memberikan vaksin terhadap anjing peliharaan mereka, bahkan membiarkan anjing peliharaan mereka lepas/berkeliaran begitu saja serta tidak mengkandangkan hewan peliharaannnya. Responsibilitas masyarakat terhadap pengendalian dan pemberantasan penyakit hewan menular rabies sangat positif karena kepedulian mereka terhadap kebijakan pengendalian dan pemberantasan penyakit hewan menular rabies sudah cukup tinggi sehingga pemerintah hanya perlu 
meningkatkannya dengan cara sosialisasi dan vaksinasi secara lebih intensif.

\section{Tingkat}

KetepatanKebijakan

Pengendalian dan Pemberantasan Penyakit Hewan Menular Rabies

Kriteria ketepatan secara dekat
berhubungan
dengan
substantive, karena pertanyaan tentang ketepatan kebijakan tidak berkenaan dengan satuan kriteria individu tetapi dua atau lebih kriteria secara bersama-sama. Ketepatan merujuk pada nilai atau harga dari tujuan program dan kepada kuatnya asumsi yang melandasi tujuan-tujuan tersebut. Kriteria ketepatan mempertanyakan apakah tujuan tersebut tepat untuk suatu masyarakat.

Berdasarkan hasil wawancara terhadap beberapa masyarakat, bahwa:

" Saya mengetahui bahwa Rabies (penyakit anjing gila) merupakan penyakit menular akut yang menyerang susunan saraf pusat pada manusia dan hewan berdarah panas yang disebabkan oleh virus rabies, ditularkan melalui saliva (anjing, kucing, kera) yang kena rabies dengan jalan gigitan. Ketepatan dalam Pertolongan pertama pada penderita rabies dapat dilakukan cara-cara seperti : (1) Cucilah luka gigitan hewan (anjing) dengan sabun / detergent di bawah air mengalir selama 10 - 15 menit ; (2) Beri obat antiseptik pada luka gigitan (obat merah, alkohol $70 \%$ dll) ; (3) Hubungi Rabies Center untuk pertolongan selanjutnya."

Dari hasil wawancara tersebut, menunjukkan bahwa masyarakat telah mengetahui adanya rabies dan bahya yang akan terjadi, sehingga melalui Dinas Komunikasi Informasi dan Statistik selaku Koordinator Media Center yang tergabung dalam Tim Koordinasi Pengendalian dan Penanggulangan Rabies di Kabupaten Kapuas Hulu telah menyediakan MediaCenter untuk pengendalian dan pemberantasan penyakit menular rabies yang sesuai dengan Surat Keputusan Bupati Kapuas Hulu, yang bertugas untuk:

a. mengkoordinir dalam penyampaian informasi pencegahan dan pengendalian rabies; dan

b. menyampaikan laporan kegiatan kepada Ketua Tim Koordinasi Pengendalian Rabies.

Dengan adanya media center diharapkan masyarakat dengan cepat dapat melaporkan kejadian kasus gigitan HPR. Media ini dibentuk untuk memudahan masyarakat yang mengalami kasus gigitan; sedangkan di tingkat kecamatan juga telah dibentuk Rabies Canter yang diketuai oleh masing-masing Kepala Puskesmas. Bahkan untuk lebih mengefektifkan pelaksanakan vaksinasi sampai di tingkat desa dan dusun, telah diterbitkan pula Keputusan Bupati Kapuas Hulu nomor 448 tahun 2016 tanggal 2 September 2016 tentang Penetapan Pos Pelayanan Terpadu Rabies Tingkat Desa di Kabupaten Kapuas Hulu. Dengan adanya media center, rabies center atau pos pelayanan terpadu (Pos Yandu) rabies diharapkan laporan kasus gigitan bisa cepat diketahui dan ditindaklanjuti; karena mencegah lebih baik daripada mengobati.

Pencegahan rabies dapat 
dilakukan dengan cara memberikan vaksin rabies pada hewan peliharaan setiap 1 tahun sekali dan segera melapor ke puskesmas/ rumah sakit terdekat bila digigit oleh hewan tersangka rabies untuk mendapatkan Vaksin Anti Rabies (VAR) sehingga penyakit menular ini dapat dicegah.

Waktu pelaksanaan vaksinasi terhadap HPR biasanya dilakukan secara bersamaan dengan kegiatan sosialisasi, dengan cara mengatur jadwal sosialisasi pada malam hari setelah masyarakat tidak ada aktifitas lagi sekaligus menginformasikan untuk pelaksanaan kegiatan vaksinasi keesokan harinya. Pelaksanaan vaksinasi diutamakan pada daerah tertular atau daerah terancam dengan kasus gigitan yang cukup tinggi; sedangkan untuk daerah aman (tidak ada laporan kasus gigitan) sementara tidak dilaksanakan vaksinasi. Hal ini mengingat keterbatasan jumah vaksin dan anggaran yang tersedia.

Penulis simpulkan bahwa aspek ketepatan telah terpenuhi dengan cukup baik. Hal ini dikarenakan masyarakat sudah mampu mengantisipasi danmelakukan tindakan pertolongan pertama dan segera melapor ke Puskesmas apabila telah terjadi gigitan HPR.

\section{SIMPULAN DAN REKOMENDASI}

\section{Simpulan}

Efektifitas Kebijakan pengendalian dan pemberatasan penyakit hewan menular rabies sudah berjalan dengan baik. Hal ini terlihat bahwa kebijakan pengendalian dan pemberantasan penyakit hewan menular rabies yang dilaksanakan sudah secara jelas memperlihatkan hasil yang maksimal dan sudah terdapat peningkatan dalam mencegah penyakit menular rabies. Kebijakan pengendalian dan pemberantasan penyakit hewan menular rabies yang dikelola langsung oleh Dinas Pertanian dan Pangan Kabupaten Kapuas Hulu, mulai tahap perencanaan sampai tahap pelaporan sangat tergantung dari kesiapan dan dukungan dari pihak-pihak terkait yang terdapat dalam Keputusan Bupati Kapuas Hulu Nomor 340 tahun 2015 tentang Kejadian Luar Biasa Penyakit Rabies.

\subsection{Rekomendasi.}

Dari hasil penelitian yang dilakukan penulis memberikan rekomendasi sebagai berikut :

Dinas Pertanian dan Pangan Kabupaten Kapuas Hulu perlu memberikan pelatihan dan bimbingan teknis kepada Kecamatan maupun Puskesmas dan Kepala Desa sebagai pengelola penyelenggaraan pengendalian dan pemberantasan penyakit hewan menular rabies.

Pihak masyarakat melalui Dinas Pertanian dan Pangan selaku leading sektor perlu menerapkan transparansi dalam setiap tahapan kegiatan mulai dari tahap perencanaan, pelaksanaan dan pertanggungjawaban dengan mengikutsertakan masyarakat terdampak rabies. 


\section{Referensi}

Arikunto, S. (1988). Prosedur penelitian Suatu Pendekatan Praktek. Jakarta : Rineka Cipta.

Badjuri, A dan Yuwono T.(2003) Kebijakan Publik : Konsep dan Strategi. Semarang: Universitas Diponegoro.

Dunn, William N . 2003. Analisa Kebijakan Publik. Yogyakarta: PT. Prasetia Widia Pratama.

Islamy, I. M. (2000). Prinsip-Prinsip Perumusan Kebijaksanaan Negara. Jakarta: Bumi Aksara.

Mustofa AR. (2002). Manajemen Proses Kebijakan Publik : Formulasi, Implementasi, dan Evaluasi Kinerja. Jakarta: Lembaga Administrasi Negara.

Moleong, J. L., (2000). Metode penelitian Kualitatif. Bandung : PT. Remaja Rosdakarya.

Nasir, Moh. (1998). Metode Penelitian. Jakarta: Balai Aksara

Nugroho, Rt. (2003). Kebijakan Publik : Formulai, Implementasi, dan Evaluasi. Jakarta: Alex Media Komputindo.

Putra, F. ( 200 ). Paradigma Kritis Dalam Studi Kebijakan Publik. Yogyakarta: Pustaka Pelajar Offset

Sugiyono,.(2003). Metode Penelitian Administrasi. Bandung. Alfabeta.

Subarsono, AG. (2005)/ Analisis Kebijakan Publik : Konsep, Teori dan Aplikasi. Yogyakarta: Pustaka Pelajar.

Tachjan, H., (2006),. Implementasi Kebijakan Publik. Bandung: Asosiasi Ilmu Politik Indonesia (AIPI).

Wibawa, S.(1994)., Kebijakan Publik Proses dan Analisis. Jakarta.
Intermedia.

Sugiyono, (2018). Metode Penelitian Evaluasi (Pendekatan Kuantitatif, Kualitatif dan Kombinasi). Bandung: CV. Alfabeta.

\section{Dokumen :}

Pedoman Pelaksanaan Vaksinasi Rabies

Petunjuk Teknis Penatalaksanaan Kasus Gigitan Hewan Penular Rabies di Indonesia

Buku Saku Petunjuk Teknis Penatalaksanaan Kasus Gigitan Hewan Penular Rabies di Indonesia

Panduan Umum Program Pengendalian dan Pemberantasan Rabies

Buku Teknis Peternakan dan Kesehatan Hewan bagi Petugas Peternakan dan Kesehatan Hewan Lapangan.

Instruksi Bupati Kapuas Hulu Nomor 1 tahun 2015 tanggal 2 Maret 2015 tentang Pencegahan Penyakit Rabies.

Instruksi Bupati Kapuas Hulu Nomor 2 tahun 2015 tentang Kewaspadaan terhadap Rabies tanggal 2 Maret 2015

Keputusan Bupati Nomor 340 tahun 2015 tanggal 19 Agustus 2015 tentang penetapan status Kejadian Luar Biasa Rabies di Kabupaten Kapuas Hulu.

Keputusan Bupati Kapuas Hulu Nomor 347 tahun 2015 tanggal 24 Agustus 2015 tentang Pembentukan Satuan Tugas Komando Tanggap Darurat Pengendalian dan Penanggulangan KLB di Kabupaten Kapuas Hulu

Keputusan Bupati Kapuas Hulu Nomor 357 tahun 2015 tanggal 15 september 2015 tentang Pembentukan Rabies Center di Empat Kecamatan di Kabupaten Kapuas Hulu, disusul Keputusan Bupati Nomor 422 tahun 2016 
tanggal 5 September 2016 tentang Pembentukan Rabies Center di Kecamatan Seberuang, Semitau, Silat Hilir, Silat Hulu, Putussibau Utara, Putussibau Selatan dan Badau di Kabupaten Kapuas Hulu

Keputusan Bupati Kapuas Hulu Nomor 448 tahun 2016 tanggal 2 Setember 2016 tentang Penetapan Pos Pelayanan Terpadu Rabies tingkat Desa di Kabupaten Kapuas Hulu.

\section{Internet :}

Pusat Data dan Informasi Kementerian Kesehatan RI, 2016.

Pusat Data dan Informasi Kementerian Kesehatan RI. 2017

Parwis, Muhammad. Teuku Reza Ferasyi, Muhammad Hambal, Dasrul, Razali, andi Novita. 2016. Kajian Pengetahuan, Sikap dan Tindakan masyarakat dalam mewaspadai Gigitan Anjing sebagai Hewan penular rabies (HPR) di Kota Banda Aceh. Diakses dari www.jurnal.unsyiah.ac.id pada hari Rabu, 3 April 2019 pukul 20.25 WIB. Mading, Majematang. Fridolina Mau, 2014. Situasi Rabies dan Upaya Penanganan di Kabupaten Flores Timur Proovinsi Nusa Tenggara (NTT). Diakses dari ejournal.litbang.depkes.go.id pada hari Rabu, 3 April 2019 pukul 20.35 WIB.

Indriaty P.B.Sopi, Ira. Fridolina Mau, 2015. Gambaran Rabies di Kabupaten Ende, Provinsi Nusa Tenggara Timur tahun 2006-2014. Diakses dari ejournal2.litbang.kemes.go.id pada hari Rabu, 3 April 2019 pukul 20.40 WIB.
Satya, Tri Putri Naipospos, 2015. Kebijakan Penanggulangan Penyakit Zoonosis berdasarkan Prioritas Departemen Pertanian. Diakses dari peternakan.litbang.pertanian.go.id pada hari Senin, 8 April 2019 pukul 14.05 WIB.

Tahulending, Jane M.F, G.D.Kandou, B. Rantag, 2015. Faktor-faktor yang Berhubungan dengan Tindakan Pencegahan Rabies di Kelurahan Makawidey Kecamatan Aertembaga Kota Bitung. Diakses dari https://ejournal.unstrat.ac.id pada hari Senin, 8 April 2019 pada pukul 14.15 WIB.

Yulia, Elisabeth Nugraha, I Wayan Batan, I Made Kardena. 2017. Sistem Pemeliharaan Anjing dan Tingkat Pemahaman Masyarakat terhadap Penyakit Rabies di Kabupaten Bangli, Bali. Diakses dari https://ojs.unud.oc.id pada hari Senin, 8 April 2019 pukul 14.25 WIB. 